\title{
Design of Male Student Dormitory Medan State University with Appropriate Site Development Concept (Green Architecture)
}

\author{
Dwira Nirfalini Aulia ${ }^{1}$, Annisa Anindita Nasution ${ }^{*}$ \\ ${ }^{I}$ Department of Architecture, Faculty of Engineering, Universitas Sumatera Utara, Medan, Indonesia
}

\begin{abstract}
Student dormitories are the residential neighborhood as student residences during their lectures. The dorms are increasing as students access different regions to study at a university. Medan city has several dorms which one is of Medan State University. This student dormitory is a special dormitory for male students of Medan State University who come from areas in North Sumatra. The condition of the dormitories is considered inadequate as a Student dormitories capacity is less than required. The existing student dormitory facilities are not complete for student dormitory facilities. It is necessary to design the male student dormitory of Medan State University. In this design, the Medan State University male student dormitory requires additional supporting facilities around the student dormitory and good building conditions. The location of the building is in the educational Area on Jalan William Iskandar Pasar V, New Memories, Percut Sei Tuan. The Male Student Dormitories applies green architecture with a basic concept approach to land use which is considered to respect every criterion contained in the land, made as comfortable as possible, responsive to the factors evaluated at the construction site.
\end{abstract}

Keyword: green architecture, medan state university

Received 21 October 2021 | Revised 21 November 2021 | Accepted 22 November 2021

\section{Introduction}

Medan State University is one of the best universities in North Sumatra, established in 1963, the Medan State Teaching and Education Institute. Then it changed its status to Medan State University in 2000 with Presidential Decree No. 124 of 1999. Medan State University began the school year in 2000/2001. Currently, Medan State University has seven faculties, namely the Faculty of Education (FIP), the Faculty of Language and Arts (FBS), the Faculty of Social Sciences (FIS), the Faculty of Mathematics and Natural Sciences (FMIPA), the Faculty of Engineering (FT), the Faculty of Sports Sciences. (FIK), Faculty of Economics (FE). The number of study programs offered is 74 study programs, consisting of 5 doctoral levels, 16 masters, 51 undergraduate, and two diplomas. The number of male students at Medan State

\footnotetext{
*Corresponding author at: Department of Architecture, Faculty of Engineering, Universitas Sumatera Utara, Perpustakaan Street J07 Building, Medan 20155, Indonesia

E-mail address: annisaaninditanst@gmail.com
} 
Universities is currently more than 12,000 people [1]. Now many universities are starting to provide public facilities and services, one of which is Medan State University as the best university in North Sumatra. Medan State University has facilities consisting of a Student Dormitory, H. Anif Student Center, Free Internet Access Service for students, Free E-mail Service for all members of Medan State University and Baiturrahman Mosque public facilities, Student Health Center ATM, Civil Servant Cooperative (KPN), Canteen/ Cafe [2].

Medan State University has provided Medan State University Student Dormitory facilities with mixed student dormitories, namely for boys and girls. Still, in the Medan State University Student Dormitory, male students are more dominant in the student dormitory of Medan State University compared to female students. Because male students living in student dormitories are from out of town and living costs in student dormitories are cheaper than living in housing around campus, this is what makes male students more likely to live in student dormitories. The more male students living in student dormitories from outside the city of Medan who want to continue their education at Medan State University, the need for housing will increase. Still, student dormitories in Medan State University cannot accommodate many male students, and The existing student dormitory facilities are not yet complete. Student Dormitory is prioritized for affirmative scholarship recipients from Papua and outside the island, recipients of Permata scholarships, Teacher Professional Education (PPG), comparative study students at Medan State University, and students from abroad [3]. The design of the male student dormitories at Medan State University needs to be designed to accommodate students who live in the Student Dormitory. For this Student Dormitory to become part of the male students of the State University of Medan, a design with Appropriate Site Development Concept (Green Architecture) is a design that is expected to reduce adverse effects on the environment and the surrounding environment [4].

Student Dormitories Medan State University has two floors. With ten rooms on one foot, two students fill one space, and inside, it has been given facilities including a bathroom, two mattresses, a cupboard, and a study table [5]. Male Student Dormitories Block A and Female Student Dormitory Block B The parts of The Student Dormitory building are a vital characteristic of the building itself. These characteristics can be seen in terms of the facade, structure, and inner space (Figure 1).

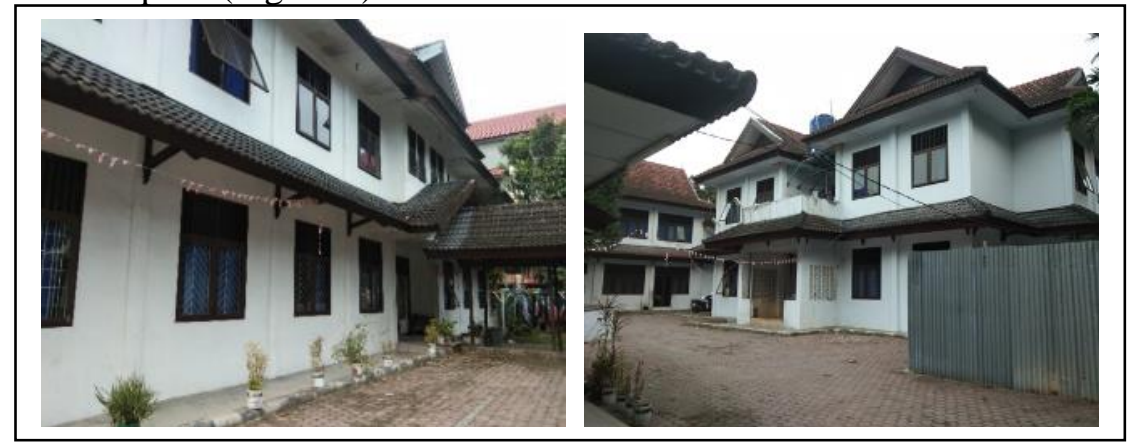

Figure 1. Male Student Dormitories Block A and Female Student Dormitory Block B 
The function of this student Dormitory building is as a Management office and a kitchen and dining room. Therefore the shape is adapted to the Student Dormitory function (Figures 2 and $3)$.

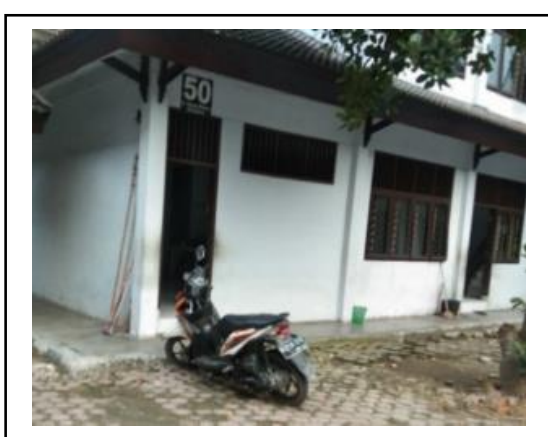

Figure 2. Management Office

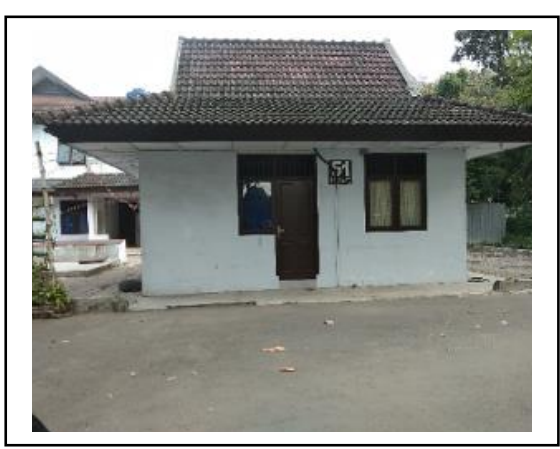

Figure 3. Kitchen and Dining Room

This Drying clothes Area for male and female students is part of the student dormitory facilities, and the sunning Area is a location outside the student dormitory building (Figure 4).
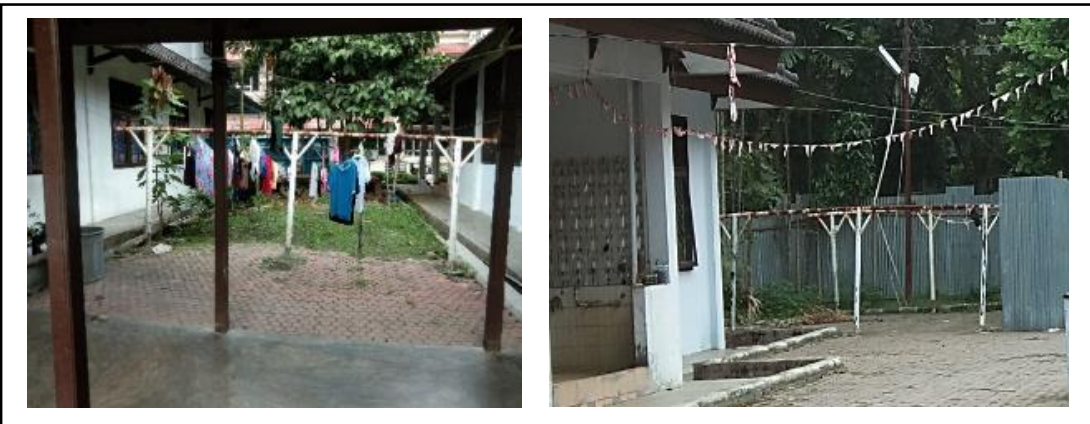

Figure 4. Drying clothes Area for male and female students

\section{Literature Review}

Definition of a dormitory, according to sources from the Ministry of Education and Culture, 1993 is a building that stays for homogeneous people. According to the Big Indonesian Dictionary, the meaning of dormitory is a residential building for a group of people, consisting of several rooms and led by the dormitory head (KBBI, 2020). According to the Big Indonesian Dictionary, a student is someone who was studying in tertiary institutions. Within the structure of education in Indonesia, students hold the highest educational status among others [6]. Medan State University is one of the best university in North Sumatra, location on Jalan William Iskandar, Pasar V Medan Estate, Percut Sei Tuan, Deli Serdang (near the border of Medan City). Over time, Medan State University has experienced much progress by providing various facilities that benefit all academics [7].

Appropriate Site Development is Urban development must be carried out to support sustainability and spatial quality in a macro manner without reducing the quality of the environment and quality of human life. In this aspect, the location and land aspects are located in the building to the surrounding environment, which is expected to influence the environment and the surrounding environment negatively. With the construction of the Student Dormitory applying the theme of Green Architecture, the Appropriate Site Development concept cannot be 
separated from its impact on the environment, such as reduced green land and environmental pollution, and unhealthy lifestyles and habits of the community [8].

Therefore, the Student Dormitory that will be planned to use the Appropriate land use concept provides better quality of the building and surrounding environment for the residents and visitors of this male Student Dormitory. Dormitory as Social Interaction In daily life in the student dormitory, students experience interacting with other students from various countries, cities, and regions. The development of urban areas that are carried out must support the sustainability of the region and the quality of space at a macro level without reducing the quality of the environment and the quality of human life. In an aspect, considered is the location and land aspects of the building to the surrounding environment, which is expected to reduce the negative influence on the environment and the surrounding environment.

\section{Methodology}

The method used in the location selection process is collecting data obtained from the site survey results. The research method used is the descriptive method, namely collecting data, both primary and secondary data. Data collection consists of background, objectives, and problems related to the draft. The next step is design analysis. At this stage, research is generated on a direct basis of field observations. The final step is the design concept. This concept was made by observing user needs, environment, analysis, studies conducted, problems found, and the solution obtained [9].

\section{Result and Discussion}

\section{Project Description}

The title of this project is the Design of Male Student Dormitory at Medan State University with Appropriate Site Development Land (Green Architecture). This project provides a Boarding facility for Male Students of Medan State University in general. This Student Dormitory is intended for Male Students at Medan State University alone. This Medan State University Student Dormitory helping students to help overcome students' difficulties in finding a place to live. The location of this project is located at Jalan William Iskandar Pasar V, Kenangan Baru, Percut Sei Tuan, Medan City. This location was chosen because it is an educational area. Many Medan State University Students come from out of town. Need a Student Dormitory for transportation to the site location. More is dominated by private cars and uses public transport. Still, few also walk to the site location because public transportation only reaches the Gate of the State University of Medan (Figure 5). 


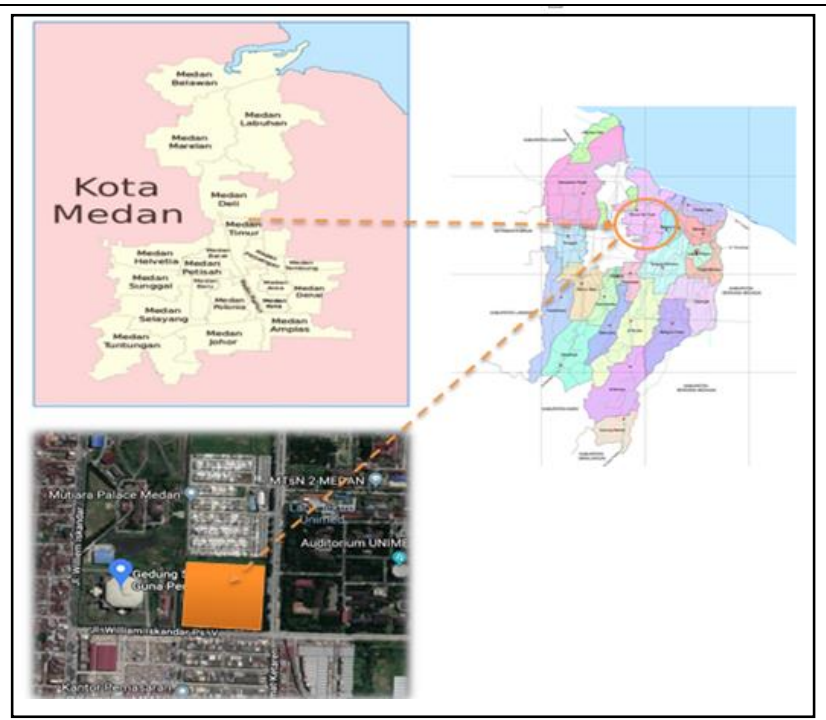

Figure 5. Map of the District of Percut Sei Tuan

Percut Sei Tuan District is a regional service center development (PPK) carried out through the program Improvement of Regional Infrastructure and Facilities, Development of Education and Sports Centers, Development of Industrial Estates in Percut Sei Tuan, Development of Warehousing and Expedition Centers, Fisheries Development and Processing, Development of Health Facilities, Improvement of Agricultural Activities Facilities [10].

Regional Boundaries

The Percut Sei Tuan sub-district areas $190.79 \mathrm{Km} 2$, consisting of 18 villages, two sub-districts, 230 hamlets, and 24 urban villages, with the district's capital is Tembung Village [11]. The village with the most expansive administrative Area is Saentis Village which has an area of 24.00 Km2. In comparison, the Area with the smallest Area is Kenangan Baru Village, a 0.72 Km2. In the east by Batang Kuis Regency and Pantai Labu Regency, in the south by Medan City, in the west by Medan City and Sub-district, Labuhan Deli [12].

\section{Basic Concept}

The basic concept in this design raises the theme of Green Architecture with the Appropriate Site Development concept, where the building function designed is the Male Student Dormitory. The basic idea of Appropriate Site Development is a response to factors that are considered in the location and land aspects of the building to the surrounding environment as well, which is expected to reduce the negative influence on the environment and the surrounding environment. Male Student Dormitory is a place of residence intended for students and as a place to interact with other students in each of the elements contained in the music. The theme of Green Architecture with the Appropriate Site Development concept approach is considered to appreciate every criterion on the land made as comfortable as possible, which is poured into the ground of the Male Student Dormitory location.

With the construction of the Student Dormitory applying the theme of Green Architecture, the Appropriate Site Development concept cannot be separated from its impact on the environment, 
such as reduced green land and environmental pollution, and unhealthy lifestyles and habits of the community. Therefore, the Student Dormitory that will be planned to use the Appropriate land use concept provides better quality of the building and surrounding environment for the residents and visitors of this male Student Dormitory [13].

\section{Zoning Concept of Outer Space}

The location for the design of the Male Student Dormitory is next to the Multipurpose Building for the North Sumatra Provincial Government. It is also on the corner of the road so that access to and exit is distinguished. Access to vehicles is from Jalan Selamat Ketaren and Jalan William Iskandar PS V as exit access. Supporting Area This is for a shared study room and watching tv together, a standard sitting room, and a room for laundry, kitchen, and dining room. This Area is for the Cooperative Room and the photocopy room, canteen, public bathroom, minimarket, warehouse, and computer room. Service Area This Area is a service for prayer that includes the mosque, ablution place, Area for managers, the manager's office, have the headroom of the manager, the archives, administration, toilets, and there is an information room, hall, and waiting room for visitors and warehouse space.

An Exterior area for parks and sports provides a gazebo for students who want to go outside and is intended for guests who visit. Vehicle parking is in front of the building. And there is a support function for outdoor zoning spaces, namely sports areas and plazas as outdoor learning areas. There is a Futsal field, and Volleyball field in the sports area in this provided for students and visitors, and in the plaza, section will be given a fountain that aims as a building conditioner. This plaza also functions as a transitional space from the outside to the building. In this plaza will also be a flower garden and vegetation that will make this Area cool. Besides that, the plaza is also given various street furniture in garden lights, seating, trash cans. On the outside Area of the building, there is a bus stop for public transportation (Figure 6).

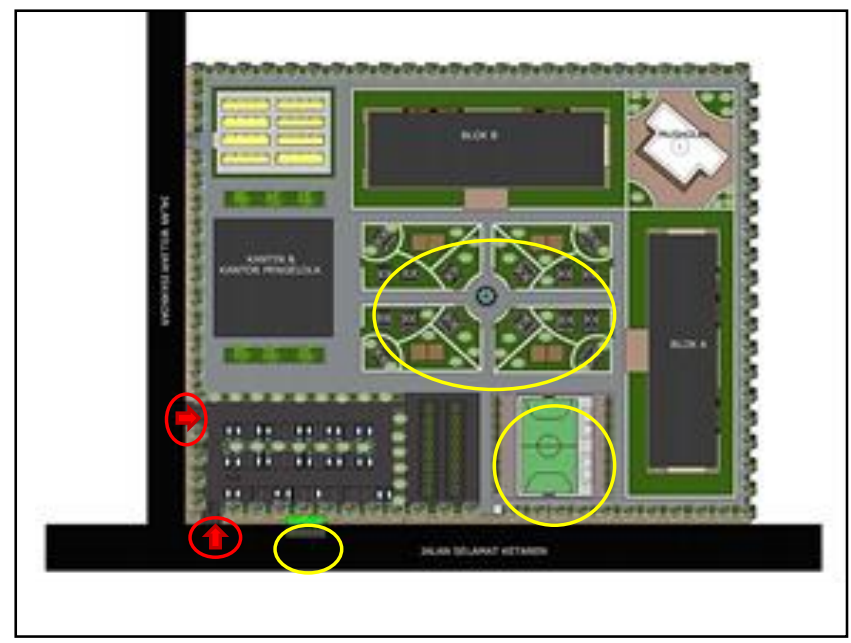

Figure 6. Zoning Concepts of Exterior Space 
Concept of Circulation

Entrance access at the Male Student Dormitory Medan State University consists of 2 pedestrians and access using vehicles. The vehicle access design has two different accesses with access in and out of the building. Admission is from Selamat Ketaren road because the building faces the front towards Medan State University, and exit access is from William Iskandar Ps V road. Pedestrian access is made from Selamat Ketaren road. Access pedestrians are in every zone of the building. The use of trees and other vegetation around access or parking as a shade for male students (Figure 7).

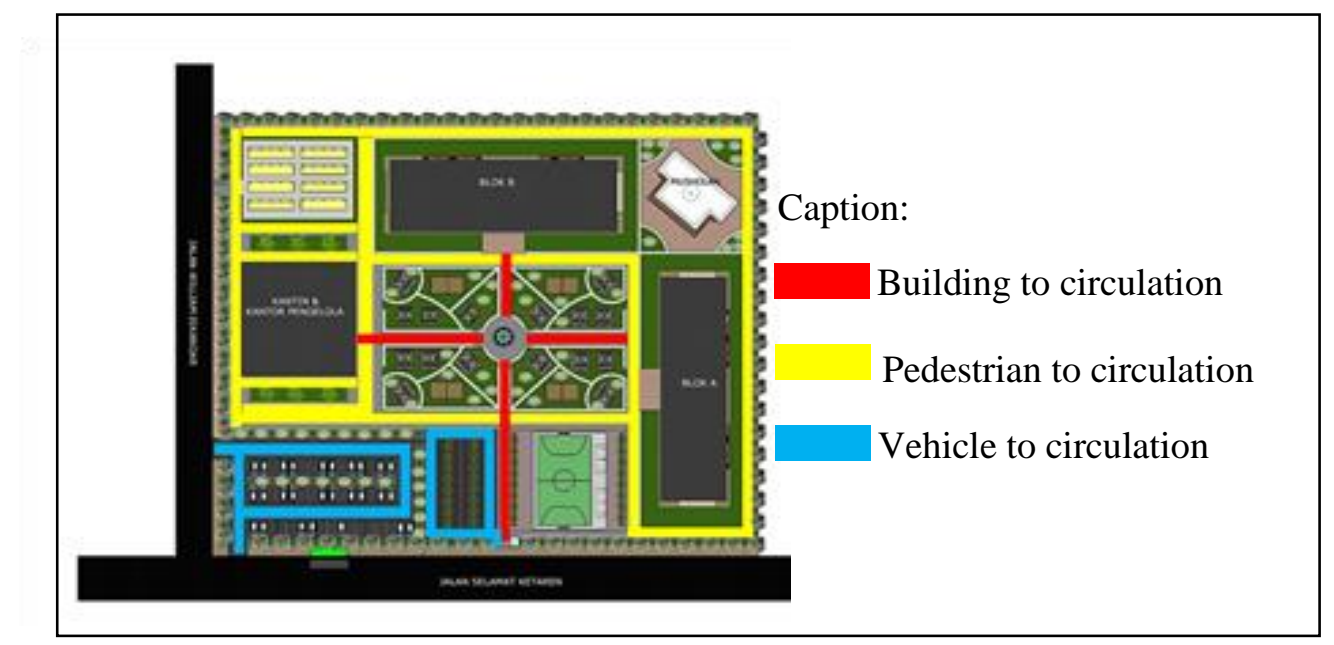

Figure 7. Concept of Circulation Vegetation

In the Area, some trees already exist and are still maintained. But there is the addition of several types of vegetation, in addition to being a buffer. This vegetation also functions to absorb pollution and noise from the road front and side of the building. The Area of selection of vegetation types is preferred on local plant types and local cultivation [14]. To provide additional points while providing added value to the surrounding environment, The types of vegetation used have benefits for buildings, including walnut, Batavia, palm, red shoots, and bamboo. All that vegetation surrounds the building and the surrounding facility area (Figure 8).

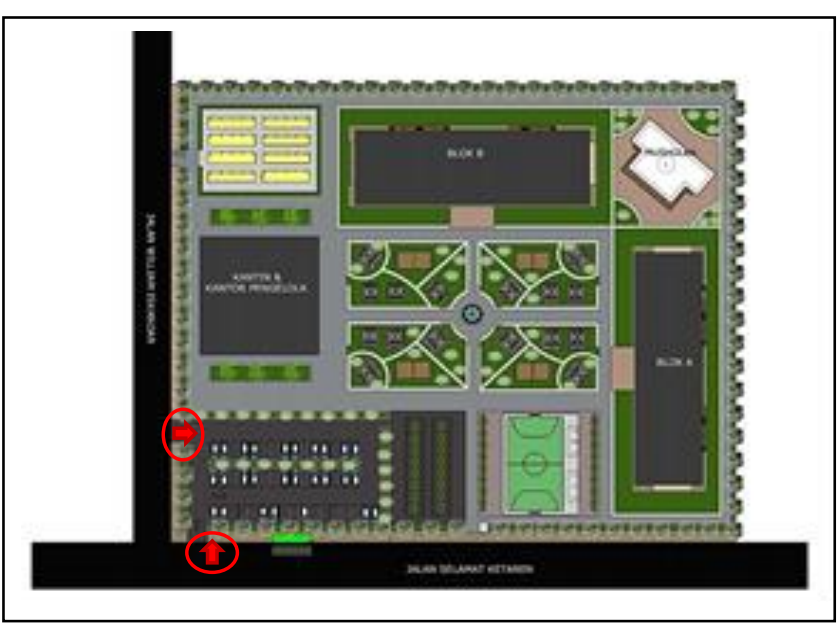

Figure 8. Vegetation Concept 
Concept View

The location of the Male Student Dormitory is at the corner of the fork in the road, and the Male Student Dormitory is designed to respond to the street corner. The part is pushed into the point of view of the building, and The building view focuses on the east, Medan State University, and south, the MMTC complex (Figure 9).

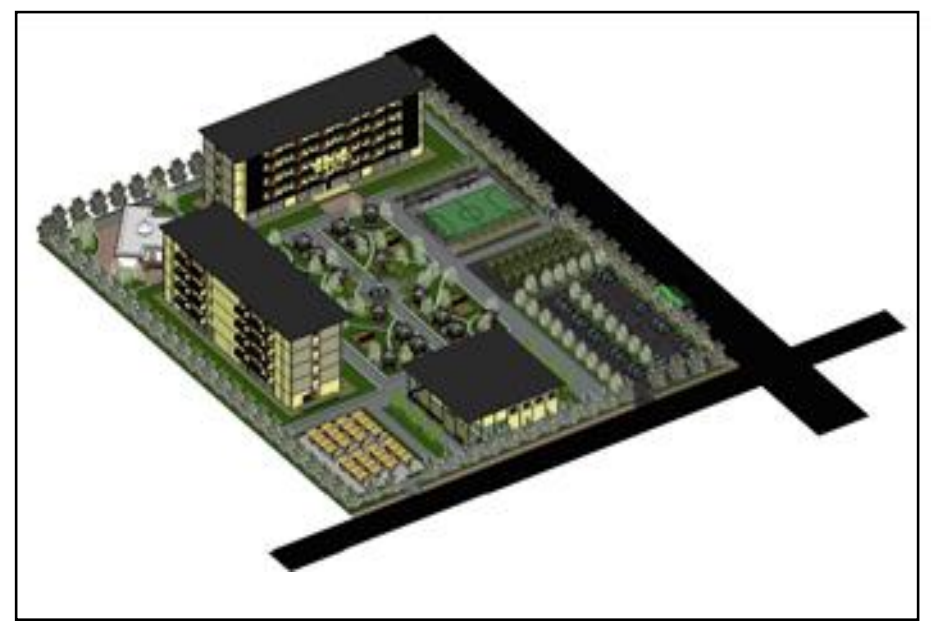

Figure 9. Concept View

Interior Design Concept

Space grouping is done to get the room quality criteria in its use. The clusters of rooms in this Student Dormitory are divided into four groups based on the nature of their activities, Public. The grouping of public spaces is based on activities that involve outside parties in their activities, such as living room, garden, parking, waiting room, and hall/lobby. Semi-private space grouping is based on activities that involve outsiders but with certain restrictions such as managers, canteens, shared study rooms, shared TV rooms, computer rooms, small mosques, kitchens \& dining rooms. Private rooms are based on activities aimed explicitly at internal student dormitory parties, namely dwellers such as bedrooms, study rooms, toilets. Service room grouping is based on activities that support the activities in this student dormitory, such as generator rooms, laundry rooms, security rooms, warehouses, and others.

The Male Student Dormitories area is divided into two blocks, each of which has two types of residential rooms for two people and three people (Figure 10 and 11).

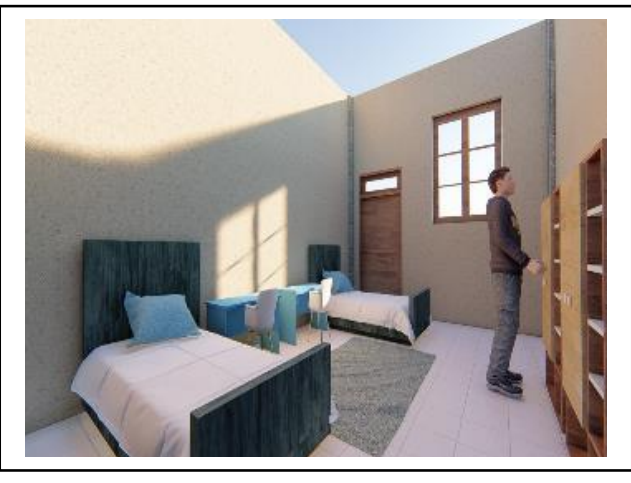

Figure 10. Interior Bedroom Blok A

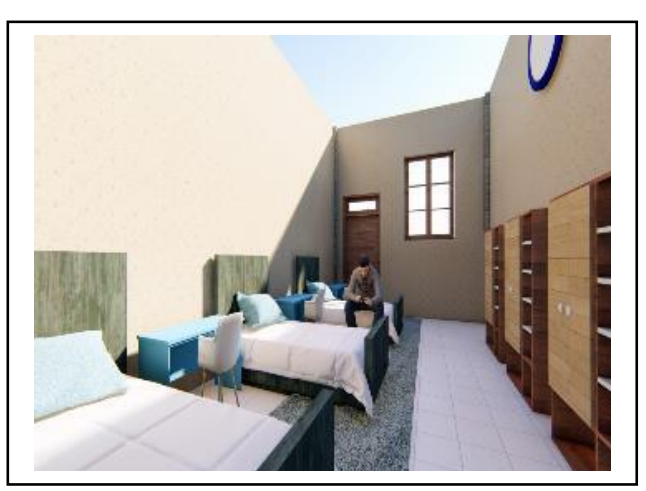

Figure 11. Interior Bedroom Blok B 
Supporting Area This is for a shared study room and watching TV together, a standard sitting room, and a room for laundry, kitchen, and dining room. This Area is for the Cooperative Room and the photocopy room, canteen, public bathroom, minimarket, warehouse, and computer room (Figure 12).

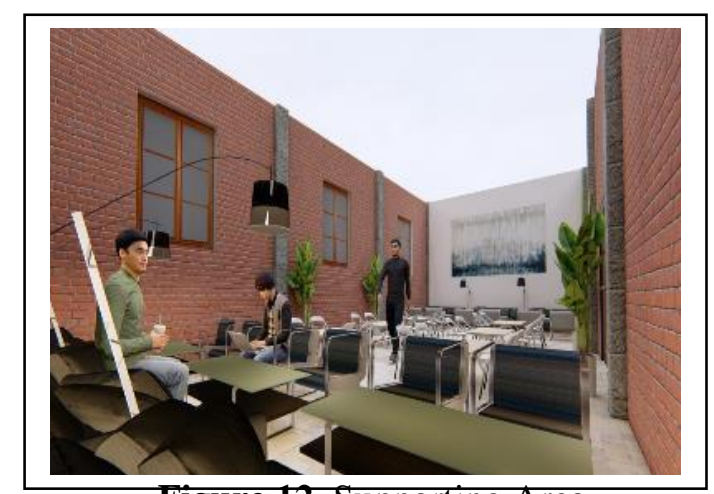

Figure 12. Supporting Area

Service Area This Area is a service for prayer that includes the mosque, ablution place, Area for managers, namely the manager's office, including the headroom of the manager, the archives, administration, toilets. There is an information room, hall, and waiting room for visitors and warehouse space, Exterior Area An area for parks and sports and provides a gazebo for students who want to go outside and also intended for guests who visit.

\section{Exterior Design Concept}

The following seven categories and criteria must be applied when designing appropriate Site Development Exterior Design concepts. Basic Green Area is Maintain or expand the city's greenness to improve the quality of the microclimate, reduce $\mathrm{CO} 2$ and pollutants, prevent soil erosion, reduce the burden on the drainage system, maintain a balance of clean water and groundwater systems. Site Selection is Avoid development in greenfields and avoid opening new land. Community Accessibility (Community Accessibility) is Encourage development in places that already have connectivity networks and increase the achievement of buildings to facilitate the community in carrying out daily activities and avoid the use of motorized vehicles (Figure 13).

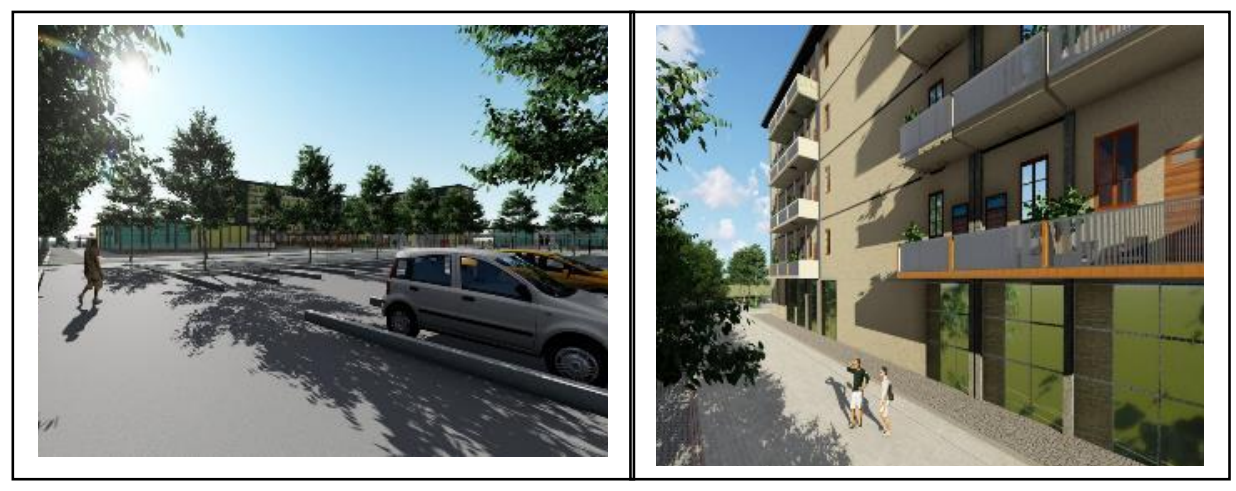

Figure 13. Community Accessibility 
Public Transportation (Public Transportation) encourages building users to use mass public vehicles and reduce private cars. The bicycle facility enables users to minimize the use of motorized vehicles to maintain the city's green to improve the microclimate quality, reduce $\mathrm{CO} 2$ and pollutants, prevent soil erosion, reduce the burden on the drainage system, maintain a balance of clean water and groundwater systems. The microclimate quality around the building includes human comfort and habitats around the environment [15].

Exterior Area An area for parks and sports and provides a gazebo for students who want to go outside and intended for guests who visit (Figure 14 and 15).
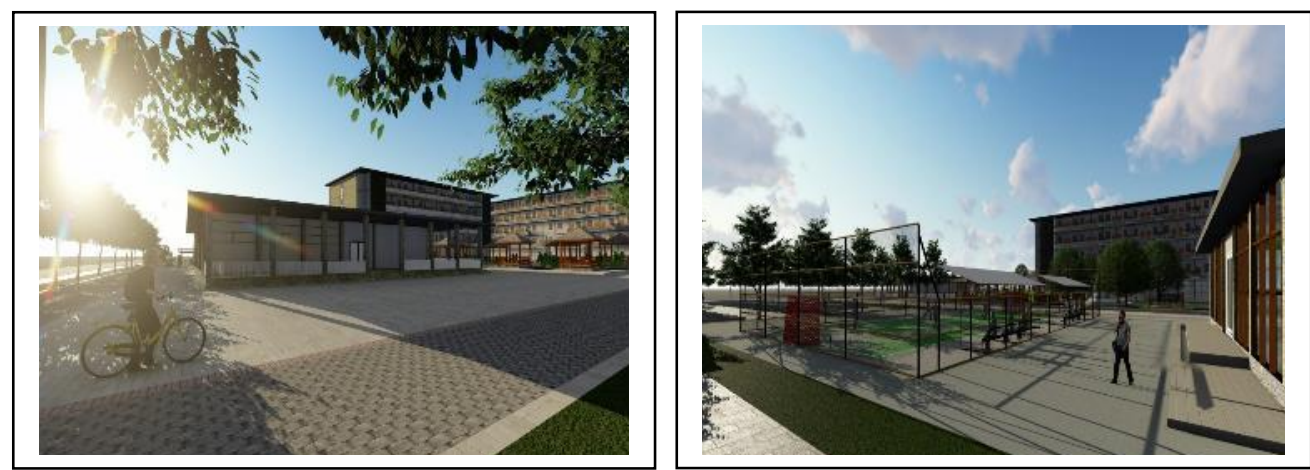

Figure 14. Exterior Area

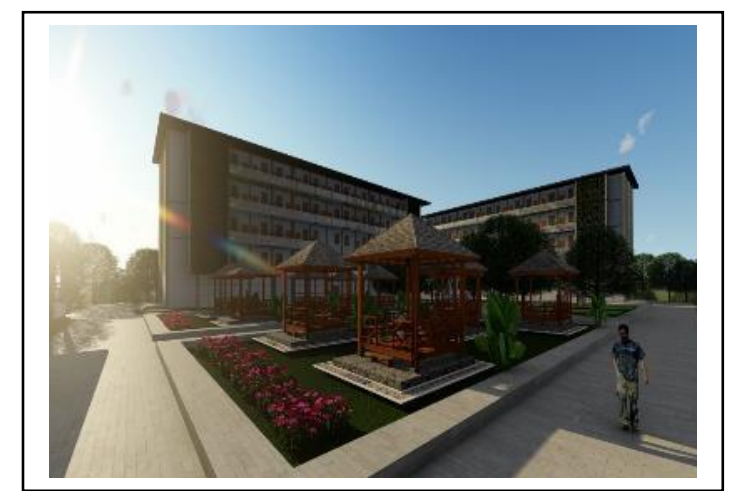

Figure 15. Exterior around the building

\section{Conclusion}

Medan State University has provided Medan State University Student Dormitory facilities, and Medan State University has mixed student dormitories for boys and girls. Still, in Medan State University student dormitories, more dominant male students live than existing girls, and student dorms do not have complete facilities. They cannot accommodate many male students, so the design of student dorms is carried out. Medan State University Student Dormitory the located at Jalan William Iskandar Ps V, Kenangan Baru, Percut Sei Tuan, Deli Serdang Regency, is designed to provide Student Dormitory facilities for male students, namely the Male Student Dormitory, which is preferred for students receiving affirmation scholarships from Papua and abroad. Islands, recipients of Permata scholarships, Teacher Professional Education (PPG), students who have taken comparative studies at Medan State University, and there are students from abroad. The design of this male student dormitory takes the theme of Green Architecture with the concept approach Appropriate Site Development, where the function of the building designed is the Male Student Dormitory. The basic concept of Appropriate Site 
Development is the response to the factors considered in aspects of the location and land in the building to the surrounding environment, which is expected to reduce the negative influence on the environment and the surrounding environment.

\section{Acknowledgment}

This research is about designing a male student dormitory with a concept of Appropriate Site Development and is intended for students of Medan State University. The author would like to thank the Department of Architecture, University of North Sumatra, for the guidance given to the author in the process of writing this research.

\section{REFERENCE}

[1] Renstra Universitas Negeri Medan 2015-2019, "Rencana Strategis Universitas Negeri Medan 2015-2019," Universitas Negeri Medan, 14 Oktober 2015 - 2019. [Online]. Available:https://www.unimed.ac.id/wpcontent/uploads/2020/10/RENSTRA_UNIMED_ REV_2015-2019_edit-2019_5SASARAN.pdf. [Diakses 27 Juni 2021].

[2] LAKIP 2016 Universitas Negeri Medan, "Laporan Kinerja 2016 Universitas Negeri Medan," $14 \quad$ Oktober 2014. [Online]. Available: file://C:/Users/User/Downloads/universitas-negeri-medan-the-character-buildinguniversity.pdf. [Diakses 10 Juli 2021].

[3] Angga Buqli Syahputra (Penjaga Asrama Mahasiswa Universitas Negeri Medan),[Interview]. 08 Oktober 2019.

[4] Andy, Hanif "Green Architecture: Konsep Desain Bangunan yang Ramah Lingkungan," ETICON, 09 Februari 2021. [Online]. Available: https://eticon.co.id/konsep-arsitekturhijau/. [Diakses 10 Juli 2021].

[5] Kementerian pendidikan dan kebudayaan Universitas Negeri Medan, "Standar Pelayanan Publik di Lingkungan Sekitar Universitas Negeri Medan," 04 Januari 2021. [Online]. Available: https://www.unimed.ac.id/wp-content/uploads/2021/04/Standar-PelayananPublik-Unimed-TA-2021-2.pdf. [Diakses 10 Juli 2021].

[6] Kustiani, Ai Siti Munawaroh "Bangunan Asrama Mahasiswa Putra (TB2) Institut Teknologi Sumatera (ITERA)," Studi Evaluasi Pasca Huni ditinjau dari Aspek Fungsional pada Bangunan Asrama Mahasiswa Putra, vol. 10, no. 1, p. 4, 2020.

[7] Universitas Negeri Medan, "Daftar Universitas Indonesia, Daftar Universitas Negeri Dan Swasta di Indonesia," Perguruan Tinggi Negeri, 04 April 2021. [Online]. Available: http://www.daftaruniversitasindonesia.web.id/universitas-negeri-medan-2/. [Diakses 10 Juli 2021].

[8] Putri, Risti Wahyuni Dwi. "Analisis pemanfaatan objek dan tingkat kemudahan pembangunan dalam kategori tepat guna lahan (Appropriate Site Development) pada green building," 21 Februari 2019. [Online]. Available: http://repository.trisakti.ac.id/usaktiana/index.php/home/detail/detail_koleksi/7/SKR/pen erbit/00000000000000096861/7. [Diakses 09 Juli 2021].

[9] Pramono,Eric. "Metode Pengumpulan Data dalam Penelitian," Universitas Ciputra Entrepreneurship Online, 08 Desember 2017. [Online]. Available: http://ciputrauceo.net/blog/2016/2/18/metode-pengumpulan-data-dalam-penelitian. [Diakses 10 Juli 2021].

[10] Kabupaten Deli Serdang, "Keterpaduan Strategi Pengembangan Kabupaten Deli Serdang," Desember $2015 \quad$ - 2019. [Online]. Available: https://sippa.ciptakarya.pu.go.id/sippa_online/ws_file/dokumen/rpi2jm/DOCRPIJM_150 0943476Bab_5_Keterpaduan_Strategi_Kab__DSR.pdf. [Diakses 09 Juni 2021].

[11] Simanungkalit. Vivi Kumala Dan Nahor arid., "Analisis Perubahan Karakteristik Desa 
Bandar Klippa Percut Sei Tuan, Deli Serdang," Ilmu Pemerintahan dan Sosial Politik UMA, vol. 1, no. 2, p. 1, 2005 - 2010.

[12] Percut Sei Tuan, "Profil Kecamatan Percut Sei Tuan," Kecamatan Percut Sei Tuan, 31 Agustus 2016. [Online]. Available: https://percutseituan.wordpress.com/2016/08/31/gambaran-umum-kecamatan-percut-seituan/. [Diakses 21 Mei 2021].

[13] Yosi Valentina Simorangkir. Anton Topan., "Asrama Mahasiswa Universitas Musamus Meurake ( Penerapan Green Architecture)," 2018 Musamus Journal of Architecture, Fakultas Teknik, Universitas Musamus, vol. 1, no. 2, p. 29, 2018.

[14] Kondisi Lingkungan Hidup dan Kecenderungannya, "Status Lingkungan Hidup Daerah Provinsi DKI Jakarta 2009," 2009. [Online]. Available: http://perpustakaan.menlhk.go.id/pustaka/images/docs/LAPORAN_SLHD_PROVINSI_ DKI_JAKARTA_TAHUN_2009_OK.pdf. [Diakses 12 April 2021].

[15] Sudarwani M Maria., "Penerapan Green Architecture dan Green Building sebagai upaya pencapaian Suistainable Architecture," Universitas Pandanaran Semarang, vol. 10, no. 3, p. 16, 2012. 